\title{
Penerapan Fungsi Manajemen Pemerintahan dalam Pelayanan Publik di Kantor Dinas Kependudukan dan Pencatatan Sipil Kabupaten Wakatobi
}

\author{
Asmal Randi Anda ${ }^{1}$; Muh. Najib Husain ${ }^{2}$; Jopang ${ }^{3}$ \\ ${ }^{123}$ Universitas Halu Oleo, asmalrandi725@gmail.com
}

\begin{abstract}
Abstrak
Penelitian ini bertujuan untuk menganalisis dan mendeskripsikan penerapan fungsi manajemen pemerintahan dalam mewujudkan pelayanan publik yang berkualitas di Dinas Kependudukan dan Pencatatan Sipil Kabupaten Wakatobi. Menggunakan jenis penelitian kualitatif yang bermaksud untuk memahami fenomena tentang apa yang dialami oleh subjek penelitian misalnya perilaku, persepsi, motivasi, serta tindakan. Teknik pengumpulan data yang digunakan yaitu observasi, wawancara dan dokumentasi. Adapun hasil penelitian dapat diuraikan bahwa penerapan fungsi manajemen dalam pelayan publik di Kantor Dinas Kependudukan dan Pencatatan Sipil Kabupaten Wakatobi sudah baik pada fungsi perencanaan, fungsi pengorganisasian, fungsi pelaksanaan, fungsi pengawasan, begitu pula dengan kualitas pelayanan publik yang terdiri dari aspek tangible, reliability, responsivines, assurance, empaty juga sudah baik namun masih memiliki keterbatasan pada aspek tangible.
\end{abstract}

Kata kunci : Manajemen, Pelayanan Publik, Penerapan, Pemerintahan

\begin{abstract}
This study aims to analyze and describe the application of government management functions in realizing quality public services in the Civil Registry Service Office of Wakatobi Regency. Using the type of qualitative research that intends to understand the phenomena about what is experienced by research subjects such as behavior, perception, motivation, and action. Data collection techniques used are observation, interviews and documentation. The results of the study can be described that the application of management functions in public service in the the Civil Registry Service Office of Wakatobi Regency is good in the planning function, organizing function, implementation function, supervisory function, as well as the quality of public services consisting of tangible aspects, reliability, responsivines, assurance, empathy are also good but still have limitations on tangible aspects.
\end{abstract}

Keywords : Management, Public Services, Implementation, Government. 


\section{Pendahuluan}

Pembukaan Undang-Undang Dasar Negara Republik Indonesia Tahun 1945 mengamanatkan bahwa tujuan didirikan Negara Republik Indonesia, antara lain adalah untuk memajukan kesejahteraan umum dan mencerdaskan kehidupan bangsa. Amanat tersebut mengandung makna negara berkewajiban memenuhi kebutuhan setiap warga negara melalui suatu sistem pemerintahan yang mendukung terciptanya penyelenggaraan pelayanan publik yang prima dalam rangka memenuhi kebutuhan dasar dan hak sipil setiap warga negara atas barang publik, jasa publik, dan pelayanan administratif.

Pelayanan publik merupakan bentuk pelayanan yang diselenggarakan oleh pemerintah kepada masyarakat dalam rangka memberikan kepuasan kepada masyarakat. Pekerjaan pelayanan merupakan pekerjaan jasa yang diselenggarakan oleh instansi pemerintah maupun perusahaan swasta dalam bidang jasa. Pelayanan publik yang masih buruk kadang menjadi tantangan sejak sebelum reformasi maupun pasca reformasi dengan kondisi yang tidak banyak yang mengalami perubahan. Namun demikian, perubahan tentu bisa dilakukan karena sesuai amanat konstitusi. Pelayanan publik menurut pasal 1 ayat (1) undang-undang nomor 25 tahun 2009, pelayanan publik adalah kegiatan atau rangkaian dalam rangka memenuhi kebutuhan pelayanan sesuai dengan peraturan perundang-undangan bagi setiap warga Negara dan penduduk atas barang, jasa, dan pelayanan administrasi yang di sediakan oleh penyellengaraan pelayanan publik.

Berdasarkan pengamatan awal bahwa penerapan fungsi manajemen pemerintahan di Dinas Kepedudukan dan Pencatatan Sipil Kabupaten Wakatobi dalam mewujudkan pelayanan publik yang berkualitas belum sepenuhnya efektif dan efisien, baik dari segi perencanaan, pelaksanaan, dan pengawasan, ketidak efektifan pelayanan Dinas Kependudukan Dan Pencatatan Sipil didasari pada rendahnya pengetahuan pegawai dan ketidakmampuan aparatur dalam memberikan pemahaman terhadap setiap tujuan pelayanan yang diberikan dengan baik kondisi yang demikian menunjukkan adanya inkonsistensi pemerintah daerah dalam bekerja dapat pula dilihat dari kurangnya pelayanan secara menyeluruh disebabkan masih banyak masyarakat yang belum merasa puas dalam pembuatan E-KTP, Akte 
Kelahiran dan Kartu Keluarga, bahkan waktu yang ditentukan dalam memberikan pelayanan kepada masyarakat belum maksimal. Kurangnya pengawasan langsung atau tidak langsung dari pimpinan terhadap bawahannya sehingga masih ada pegawai yang tidak tepat waktu yang seharusnya jam pelayanan ditentukan oleh pihak kantor pukul 07:30 pagi tetapi masih ada pegawai yang belum datang, seharusnya hal ini ditinjau oleh manajemen dengan baik.

Berdasarkan permasalahan di atas, maka penulis tertarik untuk mengkaji lebih lanjut terkait penerapan fungsi manajemen pemerintahan dalam mewujudkan pelayanan publik yang berkualitas di Kantor Dinas Kependudukan dan Pencatatan Sipil Kabupaten Wakatobi. Penelitian ini bertujuan untuk menganalisis dan mendeskripsikan penerapan fungsi manajemen pemerintahan dalam mewujudkan pelayanan publik yang berkualitas di Dinas Kependudukan dan Pencaatatan Sipil Kabupaten Wakatobi.

\section{Metode}

Penelitian ini dilaksanakan di Kantor Dinas Kependudukan dan Pencatatan Sipil Kabupaten Wakatobi. Adapun jenis penelitian yang digunakan ialah penelitian kualitatif yang bermaksud untuk memahami fenomena tentang apa yang dialami oleh subjek penelitian misalnya perilaku, persepsi, motivasi, tindakan dan lain-lain, secara holistik, dan dengan cara deskripsi dalam bentuk kata-kata dan bahasa, pada suatu konteks yang alamiah dan dengan memanfaatkan berbagai metode alamiah (Lexy J. Moleong, 2006). Agar mendapatkan jawaban dari permasalah maka informan dalam penelitian yaitu, Kepala Dinas Kependudukan dan Pencatatan Sipil Kabupaten Wakatobi, Sekretaris Dinas, Kepala Bidang Pengelolaan ADM. Kepala Bidang Kepedudukan, Kepala Bidang Pelayanan Pencatatan Sipil, Kepala Bidang Pemanfaatan Data dan Inovasi Pelayanan, Kepala Bidang Bidang Pendaftaran Penduduk, serta masyarakat pengguna layanan. Jenis data dalam penelitian ini adalah penelitian yang bersifat deskriptif kualitatif. Sumber data dapat diperolah, baik secara langsung (data primer) maupun secara tidak langsung (data sekunder) yang berhubungan dengan objek penelitian. (Arikunto, 2006: 123). 


\section{Hasil dan Pembahasan}

\section{Jenis Pelayanan di Dinas Kependudukan dan Pencatatan Sipil Kabupaten Wakatobi}

Kantor Dinas Kependudukan dan Pencatatan Sipil Kabupaten Wakatobi sebagai salah satu instansi pemerintah yang menyelenggarakan layanan masyarakat memberikan beberapa jenis jasa layanan. Layanan ini dibedakan menjadi 2, yaitu pelayanan langsung dan pelayanan online. Selanjutnya, pelayanan langsung dibagi ke dalam 2 bidang, yaitu pelayanan yang berkaitan dengan pendaftaran penduduk dan pelayanan yang berkaitan dengan pencatatan sipil. Sementara, pelayanan online yang diberikan oleh Dinas Kepedudukan dan Pencatatan Sipil Kabupaten Wakatobi meliputi pengecekan data, konsultasi data, dan pendaftaran online. Agar lebih memahami jenis layanan instansi tersebut, perhatikan tabel 1 berikut.

Tabel.1

Jenis Layanan Dinas Kependudukan dan Pencatatan Sipil Kabupaten Wakatobi

\begin{tabular}{|c|c|c|}
\hline No. & Jenis Layanan & Layanan \\
\hline \multirow[t]{4}{*}{1.} & \multirow{4}{*}{$\begin{array}{c}\text { Pendafataran } \\
\text { Penduduk }\end{array}$} & Kartu Keluarga (KK) \\
\hline & & Kartu Tanda Penduduk (e-KTP) \\
\hline & & Surat Pindah \\
\hline & & Kartu Identitas Anak (KIA) \\
\hline \multirow[t]{7}{*}{2.} & \multirow[t]{7}{*}{ Pencatatan Sipil } & Kutipan Akta Kelahiran \\
\hline & & Kutipan Akta Kematian \\
\hline & & Kutipan Akta Perkawinan \\
\hline & & Kutipan Akta Perceraian \\
\hline & & Pencatatan Pengakuan Anak dan Pengesahan Anak \\
\hline & & Pencatatan Perubahan Nama \\
\hline & & Pencatatan Perubahan Kewarganegaraan \\
\hline \multirow[t]{5}{*}{3.} & \multirow{5}{*}{$\begin{array}{c}\text { Pelayanan } \\
\text { Online }\end{array}$} & a) Cek Data \\
\hline & & - Cek NIK \\
\hline & & - Cek E-KTP \\
\hline & & -Cek Kartu Keluarga (KK) \\
\hline & & -Cek Akta Kelahiran \\
\hline
\end{tabular}




\begin{tabular}{|l|l|l|}
\hline & b) Konsultasi Data \\
\hline & c) Pendaftaran Online \\
\hline
\end{tabular}

Sumber: Dinas Kependudukan dan Pencatatan Sipil Kabupaten Wakatobi, 2019

Berdasarkan tabel di atas maka dapat pula diuraikan mengenai jenis layanan yang dilakukan oleh Dinas Kependudukan dan Pencatatan Sipil tahun 2019 yaitu jenis layanan pendaftaran penduduk terdiri dari Kartu Keluarga (KK), Kartu Tanda Penduduk (e-KTP), Surat Pindah, Kartu Identitas Anak (KIA), sedangkan pelayanan pencatatan sipil yaitu Kutipan Akta Kelahiran, Kutipan Akta Kematian, Kutipan Akta Perkawinan, Kutipan Akta Perceraian, Pencatatan Pengakuan Anak dan Pengesahan Anak, Pencatatan Perubahan Nama, Pencatatan Perubahan Kewarganegaraan. Pelayanan secara online yaitu ) Cek Data, Cek NIK, Cek E-KTP, Cek Kartu Keluarga (KK), Cek Akta Kelahiran, Konsultasi Data, Pendaftaran Online.

\section{Penerapan Fungsi Manajemen Pemerintahan}

Penerapan fungsi-fungsi manajemen adalah proses penerapan dari fungsi fungsi manajemen yaitu perencanaan, pengorganisasian, pelaksanaan dan pengawasan dalam organisasi untuk mencapai tujuan dengan efektif dan efesien

\section{a. Fungsi Perencanaan}

Perencanaan merupakan suatu proses menetapkan tujuan dan memutuskan bagaimana hal tersebut dapat dicapai. Oleh karena itu, perencanaan tidak bisa statis, tetapi harus dinamis, berkesinambungan dan fleksibel. Dinamis artinya perencanaan harus melihat kedepan, memberikan prospek secara rasional, dan segala sesuatu yang berhubungan dengan jawaban, apakah dan bagaimana harus benar-benar diperhitungkan, itulah sebabnya perencanaan harus didahului oleh suatu penjajakan yang bersifat penyidikan pendahuluan.

Terkait fungsi perencanaan hasil wawancara bersama informan yaitu Kepala Dinas Kependudukan dan Pencatatan Sipil menyatakan bahwa rencana kerja yang dilakukan melalui dokumen perencanaan untuk periode satu tahun, yang memuat kebijakan, program, dan kegiatan Dinas. Sebagai suatu dokumen resmi rencanan kerja mempunyai kedudukan strategis, yaitu menjembatani antara 
perencanaan strategis jangka menengah dengan perencanaan dan anggaran tahunan. Rencana kerja Dinas Kepedudukan dan Pencatatan Kabupaten Wakatobi untuk periode satu tahun memuat kebijakan, program, dan kegiatan yang secara umum memiliki nilai strategis dan penting antara lain Rencana Kerja Kabupaten Wakatobi, 2019.( Abdul Rahim R, 2019).

Adapun proses perencanaan kerja yang menjadi acuan penyusunan rencana kerja dinas, berupa program kegiatan SKPD, Pemohon datang ke Kantor Desa/Kelurahan setempat dengan membawa surat pengantar RT/RW dan berkas lengkap sesuai persyaratan yang telah ditentukan beserta dokumen aslinya. Mewujudkan keselarasan program dan sinkronisasi pencapaian sasaran RPJMD, menjadi bahan evaluasi rancangan peraturan daerah untuk memastikan APBD yaitu melakukan pelaporan untuk pendanaan yang telah disusun berdasarkan rencana kerja Dinas. (Jayadin, 2019).

Berdasarkan penjelasan di atas maka dari perencanaan tersebut diperoleh pula keterangan bahwa rencana kerja Kabupaten Wakatobi tahun 2019 ditetapkan dengan Peraturan Bupati setelah rencana kerja Provinsi tahun 2018 ditetapkan. Rencana kerja yang telah ditetapkan tersebut digunakan sebagai bahan evaluasi rencana perturan daerah tentang APBD Kabupaten Wakatobi tahun 2019.

\section{b. Fungsi Pengorganisasian}

Pengorganisasian merupakan proses penyusunan struktur organisasi yang sesuai dengan tujuan organisasi, sumber daya-sumber daya yang dimilikinya, dan lingkungan yang melingkupinya. Dua aspek utama proses susunan struktur organisasi yaitu departementalisasi dan pembagian kerja. Departementalisasi adalah pengelompokkan kegiatan-kegiatan kerja organisasi agar kegiatan-kegiatan sejenis saling berhubungan dapat dikerjakan bersama.

Pada aspek sumberdaya manusia, suatu organisasi jumlah pegawai harus seimbang dengan jumlah pekerjaaan dalam organisasi tersebut dengan maksud bahwa jumlah pegawai tidak berlebihan agar tidak terjadi pemborosan dan tidak kurang agar pekerjaan dapat terselesaikan dengan baik. Dari jumlah pegawai dalam pelaksanaan kegitan administrasi kependudukan dijelaskan oleh Kepala dinas 
bahwa "Jumlah personil kita belum cukup memadai, sampai saat ini jumlah pengelola administrasi kependudukan berjumlah 2 orang yang setiap hari melakukan pendataan dan perekaman data kependudukan kepada anggota masyarakat dinilai belum cukup untuk melakukan kegiatan administrasi kependudukan, oleh karena itu agar pelaksanan tugas berjalan dengan baik maka harus ada pembagian tugas yang baik agar dalam pelaksanaan perekaman data dapat berjalan dengan efektif dan lancar sehingga kegiatan pendataan penduduk terlayani secara keseluruhan (Abdul Rahim R,2019)..

Untuk lebih memudahkan pekerjaan Bidang Program dipimpin oleh seorang Kepala Bidang yang mempunyai fungsi pelaksanaan penyusunan rencana kegiatan, perencanaan, pengolahan data dan informasi, monitoring, evaluasi, dan pelaporan, untuk dapat menyelenggarakan fungsi pengorganisasian, maka bidang Program mempunyai tugas yaitu menyusun rencana kegiatan bidang program, menyusun rancangan kebijakan umum Dinas, menyiapkan bahan pelaksanaan kegiatan perencanaan Dinas, melaksanakan analisis dan penyajian data di bidang kependudukan dan pencatatan sipil, mengelola sistem informasi, pelayanan data, dan informasi pembangunan di bidang kependudukan dan pencatatan sipil. (Siti Nurbaya, 2019).

Berdasarkan penjelasan di atas maka penulis dapat menyimpulkan terkait pengorganisasian yang di lakukan oleh pihak Dinas Kependudukan dan Pencatatan Sipil Kabupaten Wakatobi sudah berjalan dengan baik, baik dilihat dari segi pembagian tugas masing-masing pegawai sesuai dengan tupoksi, maupun dalam mengarahkan masyarakat dalam melakukan pengurusan dokumen.

\section{c. Fungsi Pelaksanaan}

Pelaksanaan (actuating) adalah suatu tindakan untuk mengusahakan agar semua anggota kelompok berusaha untuk mencapai sasaran sesuai dengan perencanaan manajerial dan usaha-usaha organisasi. Jadi actuating adalah menggerakkan orang-orang agar mau bekerja dengan sendirinya atau penuh kesadaran secara bersama-sama untuk mencapai tujuan yang dikehendaki secara efektif. 
Fungsi pelaksnaan pada Dinas Kepedudukan dan Pencatatan Sipil Kabupaten Wakatobi, dapat dilihat pada hasil kerja pegawai apakah sesuai dengan tugas pokok dan fungsi. Pelaksanaan fungsi actuating, semua pegawai telah diarahkan agar mengikuti standar pelayanan minimal, semua pada tataran harus memenuhi standar pelayanan itu. Misalnya dari segi waktu, tidak boleh melebihi waktu yang ditentukan dalam menyelesaikan tugas (Kalsum, 2019).

Selain itu agar terciptanya kualitas hasil kerja yang baik, dalam menjalankan tugas harus sesuai dengan tupoksi dan tidak boleh menyimpang. Selain itu hasil kerja masing-masing bawahan juga menjadi pedoman untuk hasil kerja berikutnya. Secara teknis baik dari pusat ataupun daerah tugas-tugas itu sudah ada yang menetapkan.(Jayadin,2019).

Dari hasil penjelasan di atas dapat disimpulkan bahwa proses pelaksanaan di Kantor Dinas Kependudukan dan Pencatatan Sipil Kabupaten Wakatobi sudah berjalan dengan baik dilihat dari tanggung jawab terhadap pemanfaatan waktu kerja pun agar tugas yang diberikan selesai tepat waktu harus diperhatikan, dengan memahami seluruh uraian tugas dan fungsi sesuai dengan tanggung jawab dapat dilihat dari SOP (Standar Operasional Prosedur). Pendekatan secara personal juga merupakan langkah yang sering diambil oleh para pegawai dalam menangani masalah yang timbul antara sesama pegawai. Oleh karena itu perlu adanya penciptaan hubungan kerja sama denga pegawai lain. Dan juga membantu sesama pegawai dalam hal pelaksanaan tugas.

\section{d. Fungsi Pengawasan}

Dinas Kepedudukan dan Pencatatan Sipil Kabupaten Wakatobi melaksanakan sebagian tugas dari Direktorat Jenderal Kependudukan dan Pencatatan Sipil merupakan unsur pelaksanaan kementerian dalam negeri di bidang kependudukan dan pencatatan sipil berada di bawah dan bertanggung jawab kepada menteri. Dinas Kependudukan dan Pencatatan Sipil dalam rangka menjalankan misi selaku pelayanan publik, diperlukan adanya pengawasan dari pimpinan organisasi. Pimpinan tersebut harus memiliki pengaruh besar terhadap pencapaian tujuan organisasi. 
Berdasarkan hal tersebut Dinas Kependudukan dan Pencatatan Sipil Kabupaten Wakatobi maka pengawasan itu memiliki suatu fungsi untuk meningkatkan efektivitas kerja seperti yang diungkapkan oleh Kepala Dinas Kependudukan dan Pencatatan Sipil Kabupaten Wakatobi mengatakan bahwa "Disini yang melakukan pengawasan tentu saja pimpinan tertinggi, dalam hal ini saya sebagai Kepala Dinas. Tapi untuk mengawasi seluruh pegawai atau staf dan seluruh pelaksanaan pekerjaannya tidak mungkin karena, tugas saya bukan hanya mengawasi saja, karena sering ada tugas-tugas diluar kantor juga, jadi dilimpahkan ke Sekertaris dan Kabid- kabid untuk mengawasi staf-stafnya sendiri. Sehingga dapat dikatakan secara tidak langsung mengawasi, dan nanti hasil pengawasan akan dilakukan dengan hasil laporan kerja” (Abdul Rahim R, 2019).

Pengawasan sangat penting untuk efektivitas kerja, tingkat kerja, dan produktivitas para pegawai. Dengan pengawasan dapat diketahui capaian kerja para pegawai, dengan diketahuinya tingkat kinerja pegawai maka dapat dipertahankan, disamping itu bisa ditingkatkan, Pengawasan secara rutin dilakukan dengan mengisi absensi pegawai setiap hari dan juga mewajibkan bagi setiap pegawai untuk ijin tiap kali akan meninggalkan kantor atau meninggalkan pekerjaannya. Pengawasan berkala biasanya dilihat dari rapat kerja atau briefing yang diadakan tiap dua minggu sekali, hal yang lain dapat ditunjukkan dengan laporan hasil kerja bulanan dan laporan hasil kerja tahunan.”( Jayadin,2019)

Untuk memberlakukan pengawasan yang baik adalah pengawasan yang dilakukan secara objektif bukan subjektif. Pengawasan juga bukan sekedar mencari-cari kesalahan pegawai tetapi pengawasan yang dilakukan untuk membimbing, mendidik pegawai. Karena pengawasan yang dilakukan secara subjektif hanya akan menimbulkan efektivitas yang semua, jadi pegawai akan berlaku baik ketika dilihat saja dan akan melakukan hal yang berbeda dibelakang pimpinan.

Manajemen merupakan suatu proses, yang diartikan sebagai usaha yang sistematis untuk menjalankan suatu pekerjaan. Proses ini merupakan serangkaian tindakan yang berjenjang, berlanjut dan berkaitan, yang dilakukan untuk mencapai tujuan yang telah ditetapkan. Proses tersebut merupakan kaitan antara fungsi 
dari manajemen itu sendiri yang terdiri atas perencanaan, pengorganisasian, pelaksanaan dan pengawasan.

Pemberian pelayanan publik oleh instansi pemerintah kepada masyarakat sebenarnya merupakan implikasi dari fungsi aparatur negara sebagai penyelenggara pelayanan. Namun, kantor Dinas Kependudukan dan Pencatatan Sipil Kabupaten Wakatobi dalam memberikan pelayanan kepada masyarakat, seperti penjelasan di atas ada beberapa kendala yang ditemui serta berpengaruh dalam proses penyelenggaraan pelayanan publik yang berkualitas, antara lain 1). Kesadaran Masyarakat, salah satu faktor yang mempengaruhi pelaksanaan pelayanan publik di Kantor Dinas Kependudukan dan Pencatatan Sipil Kabupaten Wakatobi adalah faktor kesadaran masyarakat. 2) Sarana dan Prasarana, salah satu faktor komponen terjadinya proses pelayanan publik adalah sarana dan prasarana. Keberadaan sarana dan prasarana dalam menyediakan fasilitas pokok maupun penunjang proses pelayanan merupakan dasar bagi masyarakat dalam merasakan kepuasan pelayanan, karena sarana dan prasarana terlihat dan dapat dirasakan terlebih dahulu sebelum proses pelayanan terjadi.

\section{Kualitas Pelayanan Publik di Kantor Dinas Kependudukan dan Pencatatan Sipil Kabupaten Wakatobi}

Kualitas dapat diartikan sebagai kondisi dinamis yang berhubungan dengan produk, jasa, sumber daya manusia, proses dan lingkungan yang memenuhi atau melebihi harapan atau kualitas pelayanan publik yaitu sebagai perpaduan antara sifat dan karakteristik yang menentuhkan sejauh mana keluaran dapat memenuhi persyaratan kebutuhan masyarakat.

\section{a. Bukti Fisik (Tangible)}

Tangible merupakan salah satu aspek yang mempengaruhi criteria penilaian kualitas layanan, yang termasuk dalam aspek ini ialah sarana prasarana penunjang pelayanan (loket pelayanan, komputer, telepon, alat perekam KTP, papan informasi, kursi tunggu, meja pelayanan, dan tempat sampah). Selain itu, faktor kenyamanan dan kebersihan ruangan pelayanan dan ruangan penunjang layanan (mushola, kamar mandi), ketersediaan wadah aspirasi masyarakat (kotak 
saran), serta kerapian penampilan pegawai juga mendukung primanya layanan yang diberikan.

Terkait dengan aspek tangible Sekretaris Dinas Kependudukan dan Pencatatan Sipil Kabupaten menyatakan bahwa "sarana dan prasarana atau fasilitas kantor Dinas Kependudukan dan Pencatatan Sipil Kabupaten Wakatobi sudah mampu mendukung pelayanan prima kepada masyarakat walaupun masih ada yang belum secara maksimal diberikan kepada masyarakat, akan tetapi dalam memenuhi keinginan masyarakat walaupun alat yang digunakan sudah terbilang lama, seperti terbatasnya kursi papan informasi yang tidak di letakkan di tempat yang strategis dan gedung yang tidak terlalu luas namun itu tidak menjadi halangan dalam melaksanakan pelayanan tersebut"( Muhammad Kamil, 2019).

Sarana prasarana di Kantor Dinas Kependudukan dan Pencatatan Sipil Kabupaten Wakatobi sudah mampu mendukung pelayanan prima kepada masyarakat. Namun untuk lokasi di tempat saat ini dipandang kurang memenuhi persyaratan.( Abdul Rahim R,2019).

\section{b. Kehandalan (Reliability)}

Suatu pelayanan yang baik dan berkualitas perlu memiliki kehandalandan profesionalisme dalam memberikan suatu jasa dengan segera, akurat dan memuaskan. Hal ini sangat diperlukan agar tercipta kepuasan dalam diri pelanggan. Kehandalan (reliability) merupakan kemampuan memberikan pelayanan dengan cepat dan memuaskan.

Pemrosesan pengajuan layanan telah dilaksanakan secara tepat dan sesuai dengan ketentuan aturan yang berlaku. Pengurusan dan penerbitan dokumen kependudukan tidak di pungut biaya retribusi, jika terlambat pengurusannya tidak akan dikenai denda administrasi dan biaya yang dibebankan.

\section{c. Daya Tanggap (responsivenes)}

Ketanggapan atau responsiviness pegawai di Kantor Dinas Kependudukan dan Pencatatan Sipil Kabupaten Wakatobi berhubungan dengan kesiapan pegawai dalam memenuhi kebutuhan masyarakat. Daya tanggap pegawai 
dalam memberikan pelayanan menjadi salah satu aspek yang mempengaruhi penilaian masyarakat atas pelayanan yang diselenggarakan.

Berdasarkan observasi yang dilakukan peneliti, pegawai melayani masyarakat dengan baik. Pegawai merespon hal-hal yang ditanyakan masyarakat dan memberi pengarahan terkait dengan pertanyaan tersebut. Pegawai melayani dengan ramah dan sopan. Selain itu, daya tanggap atau respon pegawai juga diketahui dari hasil wawancara dengan petugas di instansi tersebut.

\section{d. Jaminan (assurance)}

Jaminan diperlukan untuk masyarakat merasa puas karena telah mendaptkan pelayanan yang baik dan berkualitas. Jaminan yang dimaksud dapat terwujud apabila pegawai di Kantor Dinas Kependudukan dan Pencatatan Sipil dapat menumbuhkan kepercayaan di hati masyarakat pemohon layanan. Agar masyarakat percaya dengan pelayanan yang diberikan, hendaknya pegawai dapat menjaga komunikasi interaksi, baik antar pegawai maupun antara pegawai dengan masyarakat di samping itu, Dinas Kependudukan dan Pencatatan Sipil Kabupaten Wakatobi hendaknya memberikan jaminan kepada masyarakat pemohon layanan.

Dinas Kependudukan dan Pencatatan Sipil telah memberikan kemudahan akses yang memudahkan masyarakat diantaranya, dokumen akta yang selesai diproses, Dinas mengirimkan (SMS) kepada pemohon untuk dapat diambil dokumen yang diurusnya. Pelayanan akta kelahiran juga telah dibuka secara online, dan memudahkan akses pelayanan kepada masyarakat". (Abdul Rahim $\mathrm{R}, 2019)$.

\section{e. Empati (Empathy)}

Dimensi Empati adalah memposisikan diri pada diri orang lain, (emphaty) meliputi kemudahan dalam melakukan hubungan, komunikasi yang baik dan memahami kebutuhan para pelanggan. Empati adalah perhatian yang dilaksanakan secara pribadi atau individu terhadap pengguna layanan dengan menempatkan dirinya pada situasi sebagai pengguna layanan. 
Berdasarkan hasil wawancara dan sesuai dengan hasil observasi selama melakukan penelitian di Kantor Dinas Kependudukan dan Pencatatan Sipil Kabupaten Wakatobi. Dapat disimpulkan bahwa empati mempunyai pengaruh yang paling dominan terhadap kepuasan masyarakat dan dalam pelayanan kepada masyarakat bahwa. Pimpinan selalu komitmen mengajarkan kepada bawahannya untuk melayani pelanggang secara efektif dan efisien dan tidak pilih kasih atau tidak di beda-bedakan dalam melakukan pelayanan.

\section{Kesimpulan}

Berdasarkan hasil penelitian dan uraian pembahasan tentang penerapan fungsi manajemen pemerintahan dalam mewujudkan pelayanan publik yang berkualitas di kantor Dinas Kependudukan dan Pencatatan Sipil Kabupaten Wakatobi, dapat diperoleh kesimpulan sebagai berikut. Fungsi Perencanaan dilakukan melalui pelayanan pembuatan dokumen-dokumen lainnya berupa Ktp, KK, Akta kelahiran dan lain sebagainya, dimana dalam pembuatanya dapat diambil dalam jangka waktu yang cepat, kemudian didasarkan dengan prosedur yang berlaku di Dinas Kependudukan dan Pencatatan Sipil Kabupaten Wakatobi. Fungsi Pengorganisasian yang di lakukan oleh pihak Dinas Kependudukan dan Pencatatan Sipil Kabupaten Wakatobi sudah berjalan dengan baik, baik dilihat dari segi pembagian tugas masing-masing pegawai sesuai dengan tupoksi, maupun dalam mengarahkan masyarakat dalam melakukan pengurusan dokumen. Fungsi Pelaksanaan di Kantor Dinas Kependudukan dan Pencatatan Sipil Kabupaten Wakatobi sudah berjalan dengan baik dilihat dari tanggung jawab terhadap pemanfaatan waktu kerja pun agar tugas yang diberikan selesai tepat waktu harus diperhatikan, dengan memahami seluruh uraian tugas dan fungsi sesuai dengan tanggung jawab dapat dilihat dari SOP (Standar Operasional Prosedur). Fungsi Pegawasan dilakukan oleh pimpinan terhadap bawahanya di Dinas Kependudukan dan Pencatatan Sipil Kabupaten Wakatobi sudah berjalan dengan baik terlihat dari sistem proses pelayanan yang diberikan kepada masyarakat.

Kualitas pelayanan publik di Kantor Dinas Kependudukan dan Pencatatan Sipil Kabupaten Wakatobi dapat dinilai dari lima dimensi yaitu, tangibles, 
reliability, responsiviness, assurance, dan emphaty. Aspek Tangible, berdasarkan hasil penelitian yang dilakukan terkait dengan bukti fisik, fasilitas pendukung pelayanan di Dinas Kepedudukan dan Pencatatan Sipil Kabupaten Wakatobi. belum memadai dan memuaskan masyarakat. Dari aspek reliability atau kehandalan, di Kantor Dinas Kependudukan dan Pencatatan Sipil Kabupaten Wakatobi telah melakukan pelayanan yang baik. Hal ini ditandai dengan cepatnya waktu pemrosesan/pembuatan produk layanan yang sesuai dengan waktu yang ada di SOP (Standard Operating Procedure), serta dalam pengurusan dokumen tidak pungut biaya, kepada masyarakat. Berdasarkan aspek responsivenes, diketahui bahwa pegawai, di Kantor Dinas Kependudukan dan Pencatatan Sipil Kabupaten Wakatobi melayani masyarakat dengan baik. Pegawai merespon hal-hal yang ditanyakan masyarakat dan memberi pengarahan terkait dengan pertanyaan tersebut. Pegawai melayani dengan ramah dan sopan. Dari aspek assurance, telah memberikan jaminan kemudahan layanan dan jaminan keamanan kepada masyarakat yang mengajukan permohonan layanan. Dan pada aspek empathy, di Kantor Dinas Kependudukan dan Pencatatan Sipil Kabupaten Wakatobi, telah memberikan pelayanan yang baik dan memuaskan. Hal ini tercapai karena pegawai yang melayani masyarakat memiliki sikap yang ramah dan sopan dalam menghadapi permintaan, kritik, dan saran yang diberikan oleh masyakat.

\section{Referensi}

Arif dan Zulkarnain. (2008). Dasar-Dasar Manajemen dalam Teknologi Informasi. Jurnal SAINTIKOM Vol. 5, No. 2 Agustus 2008

Arikunto, Suharismi. (2008). Dasar-Dasar Evaluasi Pendidikan, Jakarta: Bumi Aksara.

Christiawan, Yulius Jogi. (2002). Pengaruh Kompetensi dan Independensi terhadap Kelangsungan Usaha Kantor Akuntan Publik (KAP) di Surabaya. Jurnal Akuntansi dan Keuangan Vol.4 No. 2.

Gibson, et al. (1989). Organisasi: Perilaku, Struktur, Proses. Diterjemahkan oleh Ninuk Adriani. Jakarta: Binarupa Aksara.

Gripin, R. W. (2006) Busines, Jakarta Penerbit Erlanga. 
Hardyansyah. (2011). Kualitas Pelayanan Public, (Konsep, Dimensi, Indicator Dan Implementasinya). Yogyakarta: Gva Media.

H Rachmat. (2018). Dasar-Dasar Manajemen Pemerintahan, Bandung, Pustaka Setia

Ibrahim, Akhmadrandy. (2016). Analisis Implementasi Manajemen Kualitas Dari Kinerja Operasional Pada Industri Ekstraktif Di Sulawesi Utara (Studi Komparasi Pada Pertanian, Perikanan, dan Peternakan).Jurnal EMBA Vol.4 No.2 Juni 2016, Hal. 859-869.

Istianto Bambang. (2011). Manajemen Pemerintah Dalam Perspektif Pelayanan Publik. Jakarta: Mitra Wacana Media.

Koontz, Harold. Cyril, O’Donnell. \& Heinz, Weihrich. (2011). Manajemen. Jakarta:Erlangga.

Moleong, Lexy J. (2004). Metodologi Penelitian Kualitatif. Bandung: PT. Remaja Rosdakarya

Moleong, Lexy J.(2006). Metode Penelitian Kualitatif. Bandung: PT. Remaja Rosdakarya.

Murti, B. (2006). Desain dan Ukuran Samapel untuk Penelitian Kuantitatif dan Kualitatif di Bidang Kesehatan. Yogyakarta: Gadjah Mada University

Natzir, Moch. (2003). Metode Penelitian. Jakarta: Ghalia Indonesia.

Ndraha, Taliziduhu. (1999). Budaya Organisasi. Jakarta: Rineka Cipta.

Ndraha, Taliziduhu. (2011). Kybernology (Ilmu Pemerintahan Baru) Jakarta: Rineka Cipt

Ndraha, Taliziduhu. (2000). Ilmu Pemerintahan (Kybernology), Jakarta: Rineka Cipta.

Patton, Michael Quinn. (1987). Triangulasi. Dalam Moleong (Ed.), Metodologi Penelitian Kualitatif Edisi Revisi(hlm. 330-331). Cetakan ke-29. Bandung: PT. Remaja Rosdakarya

Putri. (2018). Pelaksanaan Fungsi Manajemen Dalam Pelayanan Masyarakat Pada Kantor Camat Moramo Utara Kabupaten Konawe Selatan, Skripsi, Universitas Halu Oleo 
Presiden Republik Indonesia. Undang-Undang Nomor 14 Tahun 2008 Tentang Keterbukaan Informasi Publik. Diakses pada 10 Agustus 2019, dari Jaringan Dokumentasi dan Informasi Hukum (JDIH) Kementerian Komunikasi dan Informatika Republik Indonesia, https://jdih.kominfo.go.id/produk_hukum/view/id/172/t/undangundang+n omor+14+tahun++2008+tanggal+30+april+2008

Presiden Republik Indonesia. Undang-Undang Nomor 25 Tahun 2009 Tentang Pelayanan Publik. Diakses pada 11 Agustus 2019, dari Jaringan Dokumentasi dan Informasi Hukum (JDIH) Badan Standardisasi Nasional, https://jdih.bsn.go.id/produk/detail/?id=17\&jns=2

Rahmat H. (2018). Dasar-Dasar Manajemen Pemerintahan, Bandung: Penerbit Pt Pustaka Setis.

Saefullah. (2008). Pengantar Manajemen, Jakarta: Kencana Prenada Media Group. Spradley dan Faisal. (1990). Format-format Penelitian Sosial. PT Rajawali Press. Jakarta.

Sukandarumidi. (2006). Metodologi Penelitian Petunjuk Praktis Untuk Penelitian Pemula, Yogyakarta: Gaja Mada Univercity Press

Sofyan Agus. (2017). Kinerja Pelayanan Kependudukan Pada Dinas kependudukan Dan Catatan Sipil Kabupaten Bandung Barat, Skripsi

Terry, George R. (2013). Prinsip Prinsip Manajemen, Bandung: Bumi Aksara.

Thoha, Miftah. (2008). Perilaku Organisasi Konsep, Dasar, dan Aplikasinya, Jakarta: Pt Raja Grafindo Persada.

Tjiptono, Fandy. (2002). Prisip-Prinsip Total Quality Service, Yogyakarta: Penerbit Andi.

Ulber Silalahi. (2009). Metode Penelitian Sosial, Bandung, PT. Rafika Aditama Winardi. (2000). Teori Organisasi Dan Pengorganisasian, Jakarta: Rajawali Pers. Wilson. (2015). Sumberdaya Mansuia, Jakarta: Erlang

Yin, Robert K. (2003).Studi Kasus: Desain \& Metode, M.Djauzi Mudjakir (penerjemah), PT. Raja Grafindo Persada, Jakarta

\section{Wawancara}


R. Abdul Rahim. (2019). Dinas Kepedudukan dan Pencatatan Sipil Kabupaten Wakatobi, 10 Agustus 2019.

Kamil, Muhammad.(2019). Dinas Kepedudukan dan Pencatatan Sipil Kabupaten Wakatobi 25 Agustus 2019.

Jayadin. (2019). Dinas Kepedudukan dan Pencatatan Sipil Kabupaten Wakatobi 18 Agustus 2019).

Nurbaya, Siti. (2019). Dinas Kepedudukan dan Pencatatan Sipil Kabupaten Wakatobi 15 Agustus 2019.

Kalsum. (2019). Dinas Kepedudukan dan Pencatatan Sipil Kabupaten Wakatobi, 15 Agustus 2019. 